\title{
Nutrient and Phytochemical Composition of Five Wild Green Leafy Vegetables Consumed in Erie-Biase Local Government Area of Cross River State
}

\author{
Ngozi Uchechi Ukam1, Mary Achi Mgbekem², Roseline Edide³, \\ Ikemefuna Christopher Obizoba² \\ ${ }^{1}$ University of Calabar, Calabar, Nigeria \\ ${ }^{2}$ University of Nigeria, Nsukka, Nigeria \\ ${ }^{3}$ Cross River State College of Education, Akamkpa, Nigeria \\ Email: achimgbekem@yahoo.com
}

Received 21 October 2015; accepted 25 July 2016; published 28 July 2016

Copyright (C) 2016 by authors and Scientific Research Publishing Inc.

This work is licensed under the Creative Commons Attribution International License (CC BY).

http://creativecommons.org/licenses/by/4.0/

c) (i) Open Access

\section{Abstract}

This work on nutrient and phytochemical composition of five wild green leafy vegetables consumed in Erei-Biase Local Government Area of Cross River State, Nigeria was aimed at identifying and determining the nutrient, and phytochemical compositions of Amaranthus viridis (Ikorodotaseach), Aeschylus glabra (Ididieriri), Alphanostylis lepthanta (Emornegbandip), Calcasia saxatilis, (Igbongonokpa) and Lonchocarpus sericeus (Ajuokoh). Analysis of moisture, protein, fiber, ash, fat and carbohydrate, micronutrients and phytochemicals was done using standard methods, while vitamins were done using AOAC, (1995). The data generated were subjected to T-test, standard deviation, standard error of the mean. The result of the proximate analysis showed that Amaranthus viridis had the highest protein value $(9.73 \%)$ and the lowest carbohydrate value $(4.60 \%)$ respectively. Aeschylea glabra recorded the highest fat value [9.73\%]. The micro nutrient result revealed that copper ( $\mathrm{CU}$ ) and phosphorous $(\mathrm{Ph})$ values were low and that the value for the other micro-nutrient differed significantly with the exception of calcium (Ca) values which did not differed significantly $(P<0.0 .05)$. The vitamins content of the vegetables differed significantly while Amaranthus viridis had the highest value of Vitamin C. The phytochemicals and anti-nutrient contents of the vegetables were moderately high but not higher than the safe levels. Hence they are recommended for consumption.

\section{Keywords}

Green Leafy Vegetables, Anti-Nutrients

How to cite this paper: Ukam, N.U., Mgbekem, M.A., Edide, R. and Obizoba, I.C. (2016) Nutrient and Phytochemical Composition of Five Wild Green Leafy Vegetables Consumed in Erie-Biase Local Government Area of Cross River State. Food and Nutrition Sciences, 7, 817-823. http://dx.doi.org/10.4236/fns.2016.79082 


\section{Introduction}

Green leafy vegetables are good sources of micronutrients [1]. They are the most available and cheapest sources of substantial amount of vitamins and minerals to the most vulnerable groups. However, in tropical Africa, millions of people still suffer from these nutrient deficiencies despite the abundance and increased consumption of leafy vegetables. These vegetables are relatively in expensive, easily and quickly cooked and rich in several nutrients, especially B-carotene and vitamin C, which are essential for human health [2]. It becomes important that the potential (nutrients, anti-nutrients and phytochemical compositions) of these green leafy vegetables, especially in the wild ones be investigated.

Considerable information is available on the nutrient composition of most well known and easily cultivated green leafy vegetables. However, there is paucity of information regarding the nutrient composition and use of other edible wild green leafy vegetables. These vegetables are either popular or on the verge of extinction among certain tribes in Nigeria. Some analysis on some of these wild vegetables showed that they are nutrient dense and need further exploitation as sources of food for both man and animal in Nigeria [3].

The global economic recession precipitated high cost of animal foods such as meat, milk, egg and crayfish as well as some popular green leafy vegetables such as fluted pumpkin (Telfeiria occidentails) and waterleaf (Talinum triangulare). This has stimulated interest of food and nutrition scientists to identify some of the wild green leafy vegetables growing in various ecosystems of Erei-Biase, Cross River State Nigeria. The thrust of this work is to determine the nutrient and chemical composition of some these wild vegetables; to meet the micro-nutrient needs of the people of Biase local Government Area, Cross River State-Nigeria. There is also a need to educate the people on the importance of increasing consumption of these vegetables to improve the nutrient quality of diets of both the children and the adults.

Nigeria is a republic in western Africa, with a coastland along the Atlantic Ocean the Guinea. About one third of Nigeria lies in the watershed of the Nigeria Rivers, which empties into the Atlantic at Niger Delta and its major tributaries. Nigeria vegetation varies at both the national and local level in relation of climate, soil, elevation and human impact on environment (Stock, [4]). Nigeria has mangrove forest at the low-lying coastal region, which has lagoons and creeks. On the other hand, swamp forest grows where the water is fresh. Farther in lands, this vegetation gives way to tropical rain forest, with its many species of tropical plants, animal and hardwoods including mahogany, Iroko, and other rich biodiversity. Towards the north, there is the savannah; a region of tall grasses and trees. Nigeria also has mountain plateaus which support a diversity of plants and animals [4].

Cross River State has both the mangrove forest which is a natural habitat to water plants and animals and tropical rain forest vegetables. It has the largest forest reserve in Nigeria. Cross River State forest has biodiversity which supports wild plants and animals. Biase Local Government Area is not left out; it has both mangrove and tropical forest vegetables with numerous wild plants. In spite of the availability of these abundant green leafy vegetables, Nigerians still suffer from micronutrient deficiency diseases. This precipitates high incidence of infant and maternal mortality of 94 deaths per 1000 live births [4]. Atinmo [5] also reported 110/1000 births as against world target of 30/1000 live births, low total life expectancy rate of 47.8 years. Population per physician is put at 3175 people (2004 estimate). The lack of information on the nutritional, anti-nutrient and phytochemical potentials of these wild vegetables is the curiosity to investigate these vegetables in some details. Based on these views, it is important to investigate and determine the anti-nutrient and phyto-chemical potentials of these vegetables.

\section{General Objectives}

The general objective if this study to identify and determine the nutrient, anti-nutrient and phyto-chemical composition of these wild green leafy vegetable consumption in Biase Local Government Area, Cross River State, Nigeria. The Specific objectives were to; identify wild/green leafy vegetables and determine the nutrient, antinutrient and phyto-chemical potentials of the wild green leafy vegetables.

The pictures of the five (5) wild green leafy vegetables.

\section{Materials and Methods}

The five wild vegetables were gathered from the forest of Erie. Plates 1-5 show the pictures of the vegetables. They included: Amaranthus viridis (Ikorodotaseada), Aeschylea glabra (Ididieriri), Calcasia saxatilis (Igbon- 


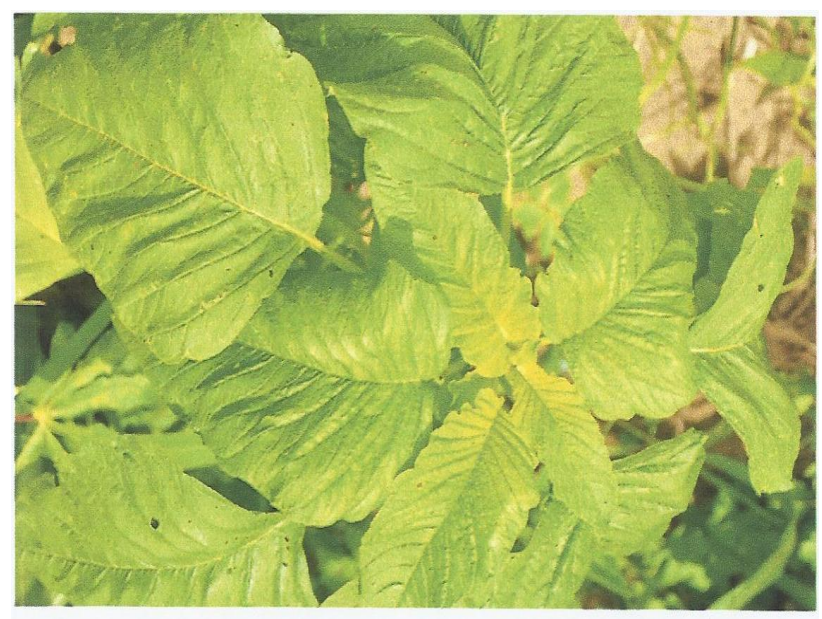

Plate 1. Amaranthus viridis (Ikorodotaseada).

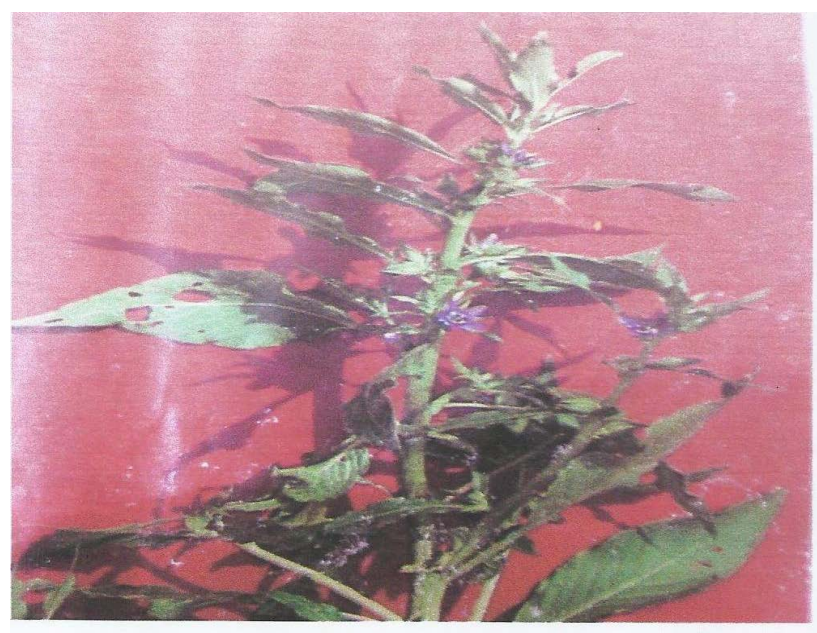

Plate 2. Aeschylea glabra (Ididieriri).

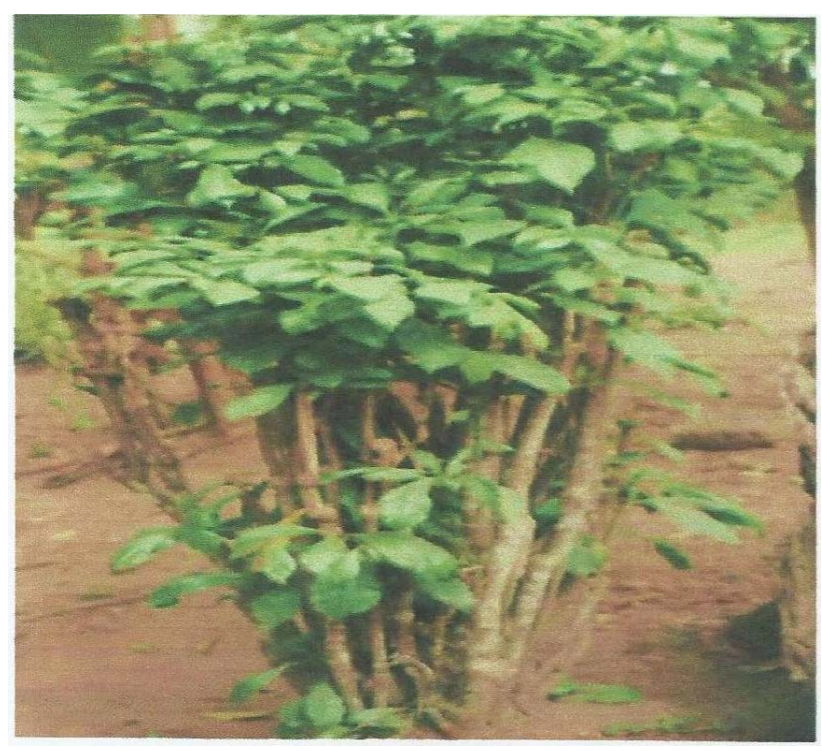

Plate 3. Culcasia saxatilis (Igbongonokpa). 


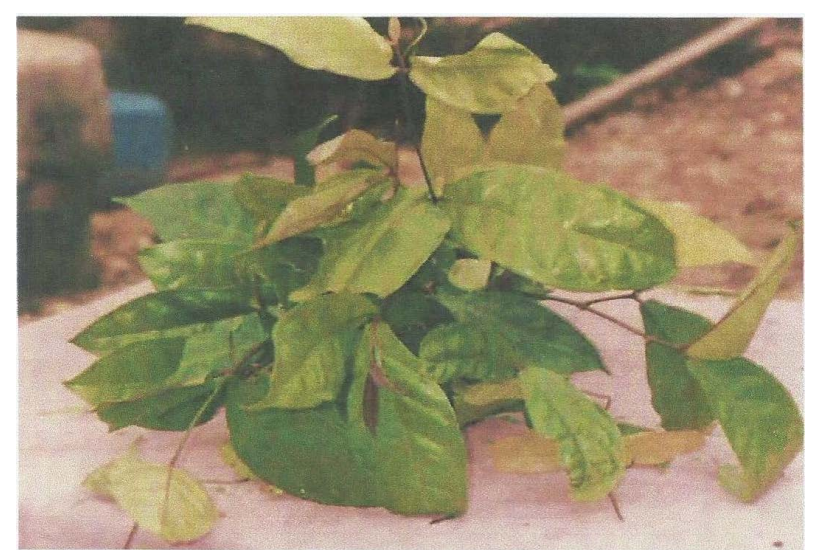

Plate 4. Aphanostylis leptantha (Emornegbandip).

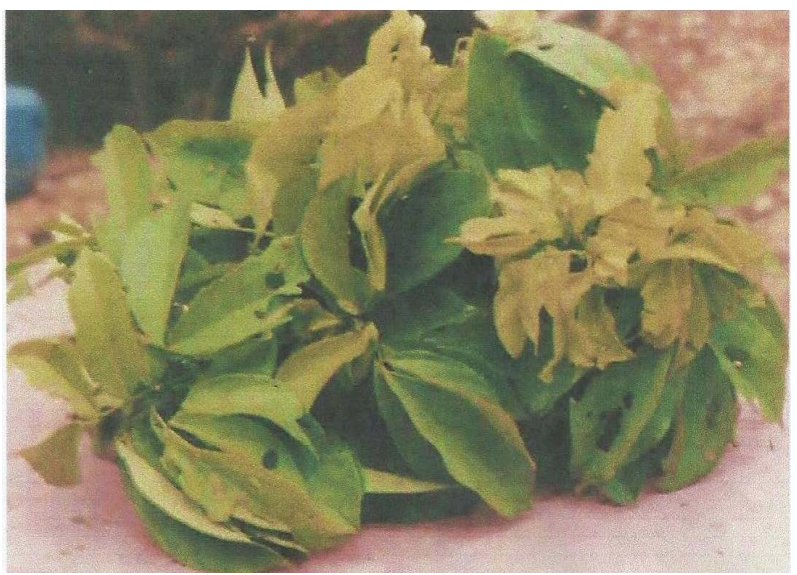

Plate 5. Lonchocarpus sericeus sericeus (Ajuokoh).

gonokpa), Alphanostylis lepthanta (Emornegbandip) and Lonchocarpus sericeus (Ajuokoh). They were identified by ten-man focus group discussion consisting of elderly men and women of Erie. The vegetables were also identified by their botanical names by two Universities herbaria; Universities of Calabar and Nigeria-Nsukka, respectively.

Moisture, protein, fibre, fat and carbohydrate, micronutrient, anti-nutrient and phyto-chemical compositions of the vegetables were determined by using standard methods [6]. The data generated from this research was subjected to standard deviation, standard error of the mean at $5 \%$ probability level and T-test to compare and contrast means, [7]. The result of this study will provide a baseline data on the nutrient, anti-nutrient, Phytochemicals contents of the five (5) wild green leafy vegetable in Biase Local Government Area. This is because there is paucity of information on the nutrition quality and food use of these vegetables. The results of this study would create and trigger household cultivation of these wild vegetables, this would in-turn provide cheap and nutritious meals, that would assist in reducing infant and maternal mortality and morbidity precipitated by micro-nutrient deficiency diseases. The result of the study would enable policy and decision makers to pay more attention to food based approach to combat micro-nutrient deficiency diseases in various communities of Biase L.G.A of Cross River State and beyond. The study would encourage the communities to consume available wild vegetables in their localities. This would be one of the effective methods to ensure household food security and improve the nutritional status and health of the people.

\section{Result and Discussion}

The proximate analysis of the five wild vegetables shows that there were significant differences across the nutrients (Moisture, Protein, Fibre, Ash, Fat and carbohydrate at 0.001 levels [Table 1]. The micronutrient compo- 
Table 1. Proximate analysis of the five wild green leafy vegetables.

\begin{tabular}{|c|c|c|c|c|c|c|}
\hline & Moisture & Protein & Fibre & Ash & Fat & CHO \\
\hline Amaranthus viridis & 61.68 & 9.73 & 1.04 & 7.13 & 9.71 & 4.60 \\
\hline Aeschylea glabra & 61.53 & 9.48 & 1.08 & 7.15 & 9.73 & 5.40 \\
\hline Alphanostylis lepthantha & 61.62 & 9.39 & 1.12 & 7.10 & 9.30 & 9.95 \\
\hline Culcasiaa saxatilis & 60.24 & 9.18 & 1.14 & 7.22 & 9.64 & 6.94 \\
\hline Lonchocarpus sericeus & 61.62 & 9.39 & 1.12 & 7.10 & 9.30 & 79.95 \\
\hline t-values & 347.975 & 197.194 & 128.255 & 585.775 & 182.659 & 2.724 \\
\hline Standard deviation (S.D.) & 0.683 & 0.185 & 0.333 & 0.047 & 0.202 & 30.378 \\
\hline Standard error (S.E.) & 0.176 & 0.04 & 0.009 & 0.012 & 0.052 & 7.884 \\
\hline Significance & $* * *$ & *** & $* * *$ & $* * *$ & $* * *$ & $* * *$ \\
\hline
\end{tabular}

Values are means of three replicates. NS—not significant; ${ }^{*}$ Significant at $0.05 ;{ }^{* *}$ Significant at $0.01 ;{ }^{* * *}$ Significant at 0.

sition of the vegetables indicated that there was significant difference (Ca, Fe,I2, Zn, Mg, Mn, K, $\mathrm{Ph}$ and $\mathrm{Na}$ ) [Table 2] expect for calcium values of the wild vegetables (2.04, 2.10, 2.34, 2.30 and 2.06mg) respectively for Amaranthus viridis (Ikorodotaseada) [Plate 1] Aeschylea glabra (Ididieriri) [Plate 2], Alphanostylis lethanta (Emornegbndip) [Plate 4], Calcasia saxatilis [Plate 3] (Igbongonokpa) and Lonchocarpus sericeus (Ajuokoh) [Plate 5] [Table 2]. The vitamin values shows that there was significant difference at 0.001 across the vegetables (vitamin A, C and E) each [Table 3]. The phytochemical mean values across the vegetables were significant at 0.001 (Alkaloids, Flavonoids, Hydrogen cyanide, Oxalate, phytate, Tannin and saponins) [Table 4].

The difference in nutrient values across the wild vegetables shows variations plants contents of nutrients (Ene-Obong, [8] [9]). The moisture values $(60.24 \%$ - 61.68\%) for the vegetables confirmed what the experts reported that fresh leafy vegetables have high Moisture content ([8] [10] \& Southgate, [11]). The amount of moisture in a food affect its keeping quality, nutrient, type and rate of microbial spoilage values of the vegetables was high $(9.18 \%-9.73 \%)$. This showed that consumption of these vegetables can reduce micronutrient deficiency diseases that are most prevalent among the vulnerable groups (Pregnant, Lactating woman and children) [Table $1]$.

The fibre values of the vegetables $(1.04 \%-1.14 \%)$ were low and comparable to the values observed by other workers [Table 1]. These low values confirmed that fresh vegetables contain low fibre because of high moisture values of the fresh vegetables [10] [11]. The high ash values of the vegetables $(7.10 \%-7.22 \%)$ indicated high content of mineral values [Table 1]. The protein values of the vegetables were high $(9.30 \%-9.73 \%)$ [Table 1]. The consumption of these vegetables could be useful for malnourished individuals and in weight management of overweight and the obese. The carbohydrate values of the vegetables were low $(4.60 \%-9.95 \%)$ This was not a surprise. This is because fresh leafy vegetables are known to contain low carbohydrate values [12] [13]. These vegetables could be included in the dietary regime of the diabetics, and in weight management of the obese. The potassium, magnesium, iodine, calcium, values were fairly high indicating the high ash content of the vegetables, while copper and phosphorus was low. These high values of minerals and proximate content indicated that the vegetables could be used to combat the prevalent incidence of micronutrient deficiencies.

The vegetables contain appreciable quantities of some phytochemicals like Alkaloids, Saponins and Flavonoids. These phytonutrients are beneficial to the human body in so many ways such as causing cancer cells to die (apoptosis), repair DNA damage caused by smoking and other toxic exposure, lower blood cholesterol (Schiavonei, [14]).

The vegetables had high oxalate values $(5.52$ - $6.34 \mathrm{mg}$ ) than safe level of $2.20 \mathrm{mg} / 100 \mathrm{~g}$ [Table 4]. This showed that heat and other traditional processing methods should be applied to reduce the level of this antinutrient. The phytate levels of the vegetables $(2.02-2.43 \mathrm{mg}$ ) were below the safe level of the $5.00 \mathrm{mg} / 100 \mathrm{~g}$ [Table 4]. This means that the level of phytate concentration in the vegetables cannot bind minerals like calcium, magnesium, iron and zinc. The tannin content of the vegetables $(2.40-2.95 \mathrm{mg})$ was higher than the safe level of tannin (0.15 - $0.20 \mathrm{mg})$. This high values help in wound healing. Finally the hydrogen cyanide (HCN) content of the vegetables (1.15 - $1.29 \mathrm{mg})$ was far below the safe level $35 \mathrm{mg}$ [14] [Table 4]. 
Table 2. Micronutrients of the five wild green leafy vegetables.

\begin{tabular}{cccccccccccc}
\hline & $\mathbf{C a}$ & $\mathbf{C u}$ & $\mathbf{F e}$ & $\mathbf{I}_{\mathbf{2}}$ & $\mathbf{Z n}$ & $\mathbf{M g}$ & $\mathbf{M n}$ & $\mathbf{K}$ & $\mathbf{P h}$ & $\mathbf{N a}$ \\
\hline Amaranthus viridis & 2.04 & 0.04 & 1.94 & 7.59 & 2.14 & 5.34 & 5.85 & 120.48 & 0.86 & 2.14 \\
Aeschylea glabra & 2.10 & 0.04 & 1.72 & 8.73 & 2.06 & 6.46 & 7.41 & 121.10 & 0.36 & 2.06 \\
Alphanostylis lepthantha & 2.34 & 0.04 & 1.72 & 8.37 & 2.09 & 5.64 & 7.32 & 120.41 & 0.38 & 2.08 \\
$\quad$ Culcasiaa saxatilis & 2.30 & 0.05 & 1.86 & 9.25 & 2.05 & 6.47 & 8.33 & 120.27 & 0.39 & 2.05 \\
$\quad$ Lonchocarpus sericeus & 2.06 & 0.04 & 1.86 & 9.46 & 2.16 & 6.15 & 6.20 & 120.42 & 0.36 & 2.16 \\
$\quad$ t-values & 2.07 & 14.19 & 77.36 & 49.27 & 167.26 & 49.76 & 29.28 & 1539.97 & 8.91 & 166.76 \\
Standard deviation (S.D.) & 0.83 & 0.11 & 0.09 & 0.68 & 0.49 & 0.47 & 0.93 & 0.30 & 0.20 & 0.49 \\
Standard error (S.E.) & 0.04 & 0.04 & 1.82 & 8.67 & 2.10 & 6.01 & 7.02 & 120.54 & 0.47 & 2.10 \\
$\quad$ Significance & $\mathrm{NS}$ & $* * *$ & $* * *$ & $* * *$ & $* * *$ & $* * *$ & $* * *$ & $* * *$ & $* * *$ & $* * *$ \\
\end{tabular}

Values are means of three replicates; NS—not significant; *Significant at $0.05 ;{ }^{* *}$ Significant at $0.01 ;{ }^{* * *}$ Significant at 0.001 .

Table 3. Vitamins contents of the five wild green leafy vegetables.

\begin{tabular}{cccc}
\hline Plant species & Vitamin A & Vitamin C & Vitamin E \\
\hline Amaranthus viridis & 1.24 & 7.13 & 0.25 \\
Aeschylea glabra & 1.04 & 5.72 & 0.23 \\
Alphanostylis lepthantha & 1.24 & 6.93 & 0.25 \\
Culcasiaa saxatilis & 1.15 & 5.32 & 0.24 \\
Lonchocarpus sericeus & 1.14 & 6.62 & 86.60 \\
t-values & 57.81 & 33.73 & 0.11 \\
Standard deviation (S.D.) & 0.08 & 0.73 & 0.19 \\
Standard error (S.E.) & 0.02 & $* * *$ & 0.00 \\
Significance & $* * * *$ & \\
\hline
\end{tabular}

Values are means of three replicates; NS—not significant; "Significant at $0.05 ;{ }^{* *}$ Significant at $0.01 ;{ }^{* * *}$ Significant at 0.001 .

Table 4. Phytochemical contents of the five wild green leafy vegetables.

\begin{tabular}{|c|c|c|c|c|c|c|c|}
\hline Plant species & Alkaloids & Flavonoids & HCN & Oxalates & Phytates & Tannins & Saponns \\
\hline Amaranthus viridis & 2.31 & 3.45 & 1.15 & 5.52 & 2.02 & 2.40 & 0.55 \\
\hline Aeschylea glabra & 2.29 & 3.09 & 1.18 & 5.54 & 2.27 & 2.59 & 0.45 \\
\hline Alphanostylis lepthantha & 2.21 & 3.75 & 1.23 & 5.87 & 2.05 & 2.85 & 0.65 \\
\hline Culcasiaa saxatilis & 2.18 & 3.38 & 1.29 & 6.34 & 2.43 & 2.95 & 0.30 \\
\hline Lonchocarpus sericeus & 2.08 & 4.21 & 1.34 & 4.77 & 2.37 & 2.76 & 0.35 \\
\hline t-values & 99.32 & 35.18 & 65.16 & 40.83 & 49.71 & 51.86 & 13.43 \\
\hline Standard deviation (S.D.) & 0.09 & 0.39 & 0.07 & 0.53 & 0.17 & 0.20 & 0.13 \\
\hline Standard error (S.E.) & 0.02 & 0.10 & 0.02 & 0.14 & 0.04 & 0.05 & 0.03 \\
\hline Significance & $* * *$ & $* * *$ & $* * *$ & $* * *$ & $* * *$ & $* * *$ & $* * *$ \\
\hline
\end{tabular}

Values are means of three replicates; NS—not significant; ${ }^{*}$ Significant at $0.05 ;{ }^{* *}$ Significant at $0.01 ;{ }^{* * *}$ Significant at 0.001. 


\section{Conclusion}

The five wild green leafy vegetables contain appreciable amount of nutrients, vitamins, minerals and phytochemicals which are beneficial to the human body. Low phytates and fairly high tannin values could help in wound healing, anti-diarrheal and anti heamorrhodial effects. The low hydrogen cyanide indicated that the vegetables are safe and justified to be consumed as vegetables.

\section{References}

[1] Ramakrishan, U. (2002) Prevalence of Micronutrients Worldwide. Nutrition Review, 60, 536-552.

[2] Ejoh, A.R., Tanya, A.N., Dankewo, N.V. and Mbefung, A.M. (2005) Effect of Processing and Preservation Methods on Vitamin and Total Carotene Levels of Some Bitter Leaf Species. African Board of Food and Nutritional Science, 5, 20.

[3] Temple, U.J. (1998) Lesser Know Plant Foods. In: Osagie, A.U. and Offiong, U.E., Eds., Nutritional Quality of Plant Foods, 245-276.

[4] Stock, R. (2009) Population per Physician. “Nigeria” Microsoft Encarnta (DVD), Remond, W.A, Microsoft Co-Operation. www.who.int

[5] Atinmo, T. and Oyowole, O.E. (2008) Nutrition Related Millennium Development Goals (NUTR-MDAS) in Nigeria: The Journey So Far Being a Lead Paper Presented at the $39^{\text {th }}$ Annual and Scientific Meeting of Nutrition Society of Nigeria. In: Nnam, N.M., Okeke, C.E., Onyechi, A.U. and Onoja, U.S., Eds., University of Nigeria, Nsukka, 24-27 September 2008.

[6] A.O.A.C (1995) Official Methods of Analysis of the Association of Official Analysis Chemists. 16th Edition, Washington DC.

[7] Obi, I.U. (1986) Statistical Methods of Detecting Differences between Treatment Means. Snapp Press Limited, Enugu, 2-28.

[8] Ene-Obong, H.N. (2001) Eat Right Calabar. The University of Calabar Press.

[9] Oguntona, T. (1989) Green Leafy Vegetables in Nutritional Quality of Plant Foods. In: Osagie, A.U. and Offiong, U.A., Eds., Post harvest Research Unit, Benin.

[10] Murano, P. (2003) Understanding Food Science and Technology. Cengage Learning, Wardsworth.

[11] Southgate, D.T. (2001) Vegetables, Fruits and Their Products. In: Garrow, J.S., James, W.P.T. and Ralph, A., Eds., Human Nutrition and Dietetics, Churchill Livingstone, London.

[12] Udofia, U.S. and Obizoba, I.C. (2005) Effect of Traditional Processing Techniques on Leafy Vegetables and Starchy Staples Consumed in Akwa Ibom State-Nigeria.

[13] Smith, F.I. and Eyzaguirire, P. (2007) African Leafy Vegetables Their Role: In World Health Organizations. Global Fruit and Vegetable Initiative Ajfand. African Journal of food Agriculture Nutrition and Development, 7, 1-17.

[14] Schiavone, A., Guo, K., Tassone, G., Gascow, L., Hermandez, E., Dentil, R.I. and Zeceoiate, I. (2007) Effect of a Natural Extract of Chestnut Wood on Digestibility, Performance Traits and Nitrogen Balance of Broiler Chick. Poultry Science, 87, 521-527. http://dx.doi.org/10.3382/ps.2007-00113

\section{Submit or recommend next manuscript to SCIRP and we will provide best service for you:}

Accepting pre-submission inquiries through Email, Facebook, Linkedin, Twitter, etc

A wide selection of journals (inclusive of 9 subjects, more than 200 journals)

Providing a 24-hour high-quality service

User-friendly online submission system

Fair and swift peer-review system

Efficient typesetting and proofreading procedure

Display of the result of downloads and visits, as well as the number of cited articles

Maximum dissemination of your research work

Submit your manuscript at: http://papersubmission.scirp.org/ 